\title{
PENGEMBANGAN GAME MULTIPLAYER PENGENALAN BUDAYA GEBUG ENDE SERAYA KARANGASEM BERBASIS ANDROID
}

\author{
I Kadek Budi Suartama1, I Gede Mahendra Darmawiguna², I Made Putrama3 \\ 1,2,3 Prodi Pendidikan Teknik Informatika Jurusan Tektik Informatika Fakultas Teknik dan Kejuruan Universitas \\ Pendidikan Ganesha, JIn. Udayana No.11 Singaraja 81116 INDONESIA
}

\begin{abstract}
Abstrak
Tujuan dari pengembangan game ini yaitu sebagai media pengetahuan game berbasis budaya yang dapat membantu masyarakat untuk lebih mengenal budaya khususnya Gebug Ende Seraya Karangasem. Memperkenalakan budaya untuk melestarikan budaya bali sangat perlu deperhatikan karena banyak tradisi dan budaya yang jarang diketahui oleh anak-anak maupun orang dewasa, permasalahan dasar yang dihadapi dalam upaya pelestarian trasdisi ini adalah kurangnya kesadaran masyarakat akan pentingnya mengetahui warisan leluhur khususnya yang ada di Bali. Pengembangan game ini mengunakan metode GDLC (Game Development Life Cycle) yang terdiri dari enam tahap, diantaranya adalah Initiation, Pre-Production, Production, Testing, Beta dan Release. Terdapat empat jenis pengujian yang dilakukan yaitu uji black box, uji ahli isi, uji ahli media dan uji tingkat pengalaman pengguna menggunakan pengujian UEQ (User Experience Questionnaire). Hasil yang telah diperoleh dari pengujian yang telah dilakukan mendapatkan respon yang sangat baik.
\end{abstract}

Kata Kunci:

Game, Gebug Ende,

GDLC

\begin{abstract}
A The purpose of developing this game is as a culture-based game knowledge medium that can help people get to know more about culture especially Gebug Ende Seraya Karangasem. Introducing culture to preserve Balinese culture really needs to be paid attention to because there are many traditions and cultures that are rarely known by children and adults, the basic problem faced in efforts to preserve this tradition is the lack of public awareness of the importance of knowing ancestral heritage, especially those in Bali. The game development uses the GDLC (Game Development Life Cycle) method which consists of six stages, including Initiation, Pre-Production, Production, Testing, Beta and Release. There are four types of tests carried out including black box test, content expert test, media expert test and user experience level test using UEQ (User Experience Questionnaire) testing. The results that have been obtained from the tests that have been carried out have received a very good response.
\end{abstract}

Keywords:

Games, Gebug Ende,

GDLC

\section{PENDAHULUAN}

Indonesia merupakan negara multikultular yang tidak hanya memiliki jumlah suku budaya berlimpah, tetapi juga tradisi keagamaan yang memiliki sejarah panjang. Setiap agama memiliki tradisi dan sejarah masing-masing, yang secara tidak langsung menjadi budaya mereka. Salah satunya terdapat di daerah Bali yang mayoritas penduduknya menganut agama hindu. Bali yang terkenal dengan tradisi dan keunikan budayanya, salah satunya adalah Gebug Ende yang merupakan tradisi khas Desa Seraya, Kabupaten Karangasem. Gebug Ende Seraya atau juga bisa disebut perang rotan, merupakan warisan budaya dan tradisi leluhur yang masih dilakoni oleh warga seraya sampai saat ini, tradisi unik ini digelar berkaitan dengan musim kemarau atau bisa dibilang untuk memohon turun hujan pada sasih Kapat

\footnotetext{
* Korespondensi

E-mail: budisuartama.com@gmail.com,mahendra.darmawiguna@undiksha.ac.id, made.putrama@undiksha.ac.id
} 
(Kalender Hindu Bali) atau pada bulan Oktober-Nopember. Letak geografis Desa Seraya pada dataran tinggi cenderung tandus, mengandalkan peran alam terutama musim penghujan sangat diharapakan, dan akan menjadi kendala jika kemarau berkepanjangan, karena itu Gebug Ende Seraya selalu digelar pada musim kemarau. Tradisi perang rotan atau Gebug Ende Seraya ini digelar di tempat-tempat umum, yang bertujuan untuk menarik lawan desa lainnya. Tidak hanya diikuti oleh orang dewasa, anak-anak juga antusias dalam mengikuti pertandingan ini. Dalam adu tanding Gebug Ende Seraya, dua peserta berhadapan siap saling serang dengan masing-masing membawa sebatang rotan sepanjang 1.5-2-meter untuk memukul lawan atau dinamakan "Gebug" dan sebuah perisai "Ende" untuk menangkis serangan lawan. Areal pertandingan tidak ditentukan ukurannya namun yang terpenting tempat tersebut datar, dan diberi pagar batas penonton. Pertandingan berlangsung sekitar 10 menit. Pemain dinyatakan kalah apabila sudah terluka atau menyerah sebelum waktu yang ditentukan habis. Peserta yang mengikuti adu tanding menggunakan pakaian adat Bali madya dengan udeng (ikat kepala) yang berwarna merah yang melambangkan jiwa keberania, bertelanjang dada dan memakai sarung. Prosesi Gebug Ende Seraya ini diiringi "gamelan" yang memacu adrenalin untuk terus bertarung dan berhenti setelah musuh terdesak. Dalam areal pertandingan dipasang sebuah batang rotan sebagai pembatas antara ke dua pemain dan tidak boleh memasuki area lawan(Club, n.d.). Seiring dengan perkembangan teknologi, banyak tradisi dan budaya yang jarang diketahui oleh anak-anak maupun orang dewasa. Permasalahan dasar yang dihadapi dalam upaya pelestarian trasdisi ini adalah kurangnya kesadaran masyarakat akan pentingnya mengetahui warisan leluhur khususnya yang ada di Bali. Sebagai generasi muda cerita rakyat, tradisi agama, maupun budaya lokal harus tetap dijaga dan dilestarikan. Kini sangat jarang ditemuai anak-anak maupun orang dewasa yang mengetahui tradisi yang ada di Bali, justru budaya dan tradisi luar negeri yang mereka gemari, baik melalui buku-buku, internet maupun game yang mereka gemari. Teknologi tidak hanya membawa dampak negatif terhadap budaya, namun teknologi juga dapat dijadikan sebagai sarana pelestarian budaya, salah satunya dengan memanfaatkan game telah menjadi tren dan banyak digemari baik dikalangan anak-anak, dewasa, maupun tua, sehingga dengan memadukan tradisi dengan game, kita dapat menyampaikan nilai-nilai moral, Pendidikan, ataupun budaya yang terkandung dalam game tersebut. Game produksi jepang telah banyak digunakan sebagai media penyampaian budaya, beberapa diantaranya adalah Okami dan Oboro Muramasa yang dirilis untuk kosol Play station 2 dan Nitendo WII. Game bersifat menyenangkan, dan memunculkan rasa ingin tahu terhadap permainannya, sehingga game bertemakan budaya sangat baik untuk dikembangkan sebagai sarana untuk Pendidikan, penyampaian informasi dan sebagai hiburan. (Utomo \& Lakoro, 2012) Pada zaman sekarang setiap anak pasti mengenal game, mereka rela bermain game hingga lupa waktu belajar, membantu orang tua, dan bahkan tidak menghiraukan teman yang lainya. Kebanyakan dari mereka suka memainkan game tersebut melalui komputer (PC) ataupun Smartphone. hal ini dapat diketahui melalui penyebaran kuesioner yang dilakukan oleh peneliti ke beberapa tempat. Kesimpulan yang peneliti dapatkan dari penyebaran kuesioner yaitu responden sangat antusias dan mengharapkan game yang akan peneliti kembangkan dapat terealisasikan. Selain itu responden juga mengharapkan game yang akan dikembangkan mudah untuk dimainkan dan tidak berpengaruh buruk pada perangkat yang mereka gunakan. Sebelum penelitian ini dilakukan, beberapa peneliti lain telah merancang budaya sebagai game, salah satunya adalah game yang dibuat oleh Nyoman Trisna Adi Darma yang berjudul "Pengembangan Aplikasi Game Kisah Panji Sakti Berbasis Mobile",(Nyoman Trisna Adi Darma, I Ketut Resika Arthana, 2017) namun game ini masih menggunakan visual 2D (dua dimensi). Game yang dibuat oleh B. Abdus Somad Rajab yang berjudul "Perancangan Game Fighting Peresean Sebagai Media Pengenalan Budaya Suku Sasak"(Rajab \& Kuswantoro, 2018), namun game ini tidak dirancang untuk Mobile melainkan personal komputer. Berdasarkan dari data-data tersebut, peneliti tertarik mengembangkan aplikasi berbasis Android tentang kebudayaan yang berjudul "Pengembangan Game Multiplayer Pengenalan Budaya Gebug Ende Seraya Karangasem Berbasis Android".

\section{METODE}

Metode pengembangan dalam penelitian ini menggunakan GDLC (Game Development Life Cycle), metode ini merupakan pengembangan dari beberapa ahli sebelumnya sehingga lebih runtut dan terperinci dalam langkah-langkah pembuatan sebuah game(Teknosecret, 2019). Berikut tahapan dalam pengembangan game menggunakan metode GDLC

Metode pengembangan dalam penelitian ini menggunakan GDLC (Game Development Life Cycle), metode ini merupakan pengembangan dari beberapa ahli sebelumnya sehingga lebih runtut dan terperinci didalam langkah-langkah pembuatan sebuah game. Berikut tahapan dalam pengembangan game menggunakan metode GDLC.

1. Initation 
Pada tahap ini akan dilakukan pembuatan konsep game yang akan dibangun, berupa analisa akan seperti apa game itu dibangun, initiation akan menghasilkan konsep game dan deskripsi sederhana game Menurut buku yang berjudulu The Art of Game Design_A Book of Lenses (Schell, 2014) terdapat 113 Lenses Theory, dan peneliti menggunakan 19 dari 113 Theory Lenses yang ada.

2. Fre-Production

Tahapan ini merupakan tahapan sebelum production, dimana pada tahapan ini dilakukan perancangan dan membuat desain game. Desain game berfokus untuk menjelaskan gameplay, karakter, alur sistem, tampilan antar muka, kebutuhan fungsional dan kebutuhan fungsional

3. Gameplay

Gameplay merupakan cara tertentu dimana pemain game berinteraksi dengan permainan. Gameplay adalah pola yang diterapkan melalui peraturan dalam permainan, hubungan antara pemain dengan permainan dimana pemain mengatasi tantangan dalam game. Gameplay game Multiplayer Pengenalan Budaya Gebug Ende Seraya Karangasem Berbasis Android dalam mode Versus dan Turnamen

4. Production

Setelah tahapan Pre-production selesai maka dilanjutkan ketahap Production, dalam tahapam production berisi kegiatan rancangan yang telah dibuat sebelumnya diimplementasikan dengan perangkat lunak yang telah disesuaikan. Pada tahapan ini dilakukan perancangan asset yang akan dipakai, perancangan

5. Testing

Pada tahapan Testing dilakukan pengukuran tingkat keberhasilan aplikasi yang telah dibuat peneliti. Pengujian ini bertujuan untuk mengetahui kekurangan maupun kewalahan (error) yang terjadi pada aplikasi game yang dikembangkan, sehingga aplikasi game dapat diperbaiki untuk memperbaiki kekurangan yang teradi sebelumnya. Pengujian focus pada perangkat lunak baik dari segi logika maupun dari segi fungsional. Jenis pengujian pada tahap Testing meliputi Uji Black Box, Uji Ahli Isi, Uji Ahli Media, Uji UEQ.

6. Release

Setelah tahap pengujian Game Multiplayer Pengenalan Budaya Gebug Ende Seraya Karangasem Berbasis Android, selanjutnya game yang sudah selesai dibuat disimpan dalam bentuk file *.apk. Setelah itu file tersebut didistribusikan ke masyarakat umum untuk dapat dimainkan dan dapat membantu masyarakat mengenal cerita rakyat lebih baik lagi sebagaimana mestinya.

\section{HASIL DAN PEMBAHASAN}

\section{A. Hasil Tahap Initation}

Rincian Analisis Berdasarkan Lenses Theory

1. Menu Utama

1) Penggunaam Lenses Theory Pada Game "Gebug Ende Seraya"

A) No 67 The Lens of Modes: Implementasi dari lens teori ini, pengembang telah merancang 2 mode yaitu mode versus dan mode turnamen.

2. Game Mode Versus

1) Penggunaam Lenses Theory Pada Game "Gebug Ende Seraya"

A) No 43 The Lens of Competition: Implementasi dari lens teori ini, pengembang telah menambah papan peringkat, papan peringkat ini merupakan tampilan skor akhir dari setiap pengguna.

B) No 3 The Lens of The Venue: Implementasi dari lens teori ini, pengembang telah mendesain game berteakan nuansa bali.

C) No 12 The Lens of Resonance: Implementasi dari lens teori ini, pengembang telah mengembangkan game yang memiliki kelebihan fitur multiplayer berbasis online.

D) No 33 The Lens of Rules: Implementasi dari lens teori ini, pengembang telah menambahkan peraturan dalam game. Seperti darah akan berkurang ketika pemain terkena serangan musuh.

E) No 34 The Lens Of Skill: Implementasi dari lens teori ini, pengembang telah menambah kemampuan jurus yang dapat digunkan untuk mepermudah mengalahkan musuh.

F) No 39 The Lens Of Meaningful Choices: : Implementasi dari lens teori ini, pengembang mampu membuat lebih dari 1 karakter dalam game. 
G) No 46 The Lens of Reward: Implementasi dari lens teori ini, pengembang telah menambah poin kepengguna ketika berhasil memenangkan permainan.

H) No 50 The Lens Of Character: Implementasi dari lens teori ini, pengembang telah membuat karakter utama game sesuai dengan budaya lokal yaitu seorang petarung dari penduduk asli desa seraya.

I) No 64 The Lens of Juiciness: Implementasi dari lens teori ini, pengembang telah membuat interface poin pengguna saat berhasil memenangkan permainan.

J) No 52 The Lens of Economy: Implementasi dari lens teori ini, pengembang telah menambah fitur belanja.

3. Game Mode Turnamen

1) Penggunaam Lenses Theory Pada Game "Gebug Ende Seraya"

A) no 3 The Lens of The Venue: Implementasi dari lens teori ini, pengembang telah mendesain game berteakan nuansa bali.

B) No 5 The Lens of Fun: Implementasi dari lens teori ini, pengembang telah mendesain pertarungan akan terbuka apabila pengguna dapat melewati pertarungan sebelumnya.

C) No 32 The Lens of Goals: Implementasi dari lens teori ini, pengembang telah menambah tujuan di awal permainan.

D) No 33 The Lens of Rules: Implementasi dari lens teori ini, pengembang telah menambahkan peraturan dalam game. seperti darah akan berkurang ketika pemain terkena serangan musuh.

E) No 34 The Lens Of Skill: Implementasi dari lens teori ini, pengembang telah menambah kemampuan jurus yang dapat digunkan untuk mepermudah mengalahkan musuh.

F) No 38 The Lens Of Challenge: Implementasi dari lens teori ini, pengembang telah membuat kekuatan musuh yang berbeda dalam setiap pertarungan.

G) No 39 The Lens Of Meaningful Choices: Implementasi dari lens teori ini, pengembang mampu membuat lebih dari 1 karakter dalam game.

H) No 46 The Lens of Reward: Implementasi dari lens teori ini, pengembang telah menambah poin ke pengguna ketika berhasil memenangkan permainan.

I) No 50 The Lens of Character: Implementasi dari lens teori ini, pengembang telah membuat karakter utama game sesuai dengan budaya lokal yaitu seorang petarung dari penduduk asli desa seraya.

J) No 52 The Lens Of Economy: Implementasi dari lens teori ini, pengembang telah menambah fitur belanja.

K) No 53 The Lens Of Balance: Implementasi dari lens teori ini, pengembang telah tambahan darah ketika berhasil mengalahkan musuh.

L) No 57 The Lens Of Phyramid: Implementasi dari lens teori ini, pengembang telah membuat permainan dimulai dari melawan musuh dari tingkatan mudah hingga tersulit.

M) No 63 The Lens Of Feedback: Implementasi dari lens teori ini, pengembang telah membuat petunjuk berupa informasi tentang musuh saat akan melanjutkan ke pertarungan selanjutnya.

N) No 64 The Lens of Juiciness: Implementasi dari lens teori ini, pengembang telah membuat interface yang dapat memberi umpan pada tiap aksi yang dilakukan pemain.

\section{B. Hasil Tahap Pre-Production}

Analisis Kebutuhan - Kebutuhan Baik Kebutuhan Fungsional Dan Kebutuhan Non Fungsional.

\section{a Kebutuhan Fungsional}

Berikut merupakan kebutuhan fungsional dari implementasi lenses theory dalam pembuatan Game Multiplayer Pengenalan Budaya Gebug Ende Seraya Karangasem Berbasis Android"

a. Mampu memulai permainan multiplayer berbasis online. 
b. Mampu menampilkan sejarah gebug ende seraya sebelum pertarungan 1 dimulai.

c. Mampu melanjutkan permainan ke pertarungan 2 apabila pengguna telah menyelesaikan Mertarungan 1 mode turnamen.

d. Mampu melanjutkan permainan ke pertarungan 3 apabila pengguna telah menyelesaikan Mertarungan 2 mode turnamen.

e. Mampu melanjutkan permainan ke pertarungan 4 apabila pengguna telah menyelesaikan pertarungan 3 mode turnamen.

f. Mampu mengurangi hp (health point) karakter yang dimainkan pengguna ketika terkena serangan musuh.

g. Mengguna mampu mengakses shop dan membeli item yang nantinya digunakan untuk memperlancar melawan musuh yang terdapat pada game.

h. Mengguna mampu mendapat reward dalam kurun waktu tertentu yang terdapat dalam semua pertarungan.

\section{b Kebutuhan Non-Fungsional}

Pengembangan game ini merancang agar dapat mengimplementasikan kebutuhan non fungsional sebagai berikut :

a. Dalam kebutuhan fungsionalnya game ini akan diukur user experience-nya menggunakan UEQ (User Experience Questionnaire).

1) Cerita dalam Permainan

Disebuah desa yang banyak penduduknya, ada sebuah tradisi yang kental yaitu tradisi gebug ende, yaitu tradisi perang rotan yang diadakan di setiap datangnya musim kemarau, yang bertepatan pada bulan Oktober - November pada kalender bulan bali. Karena desa ini terletak di sebuah pegunungan, pada saat musim kemarau para penduduk kesuliatan dalam mencari air, maka dari itu untuk memohon turunnya hujan mereka mengadakan tradisi gebu gende yang diyakini bisa menurunkan hujan. Namun untuk bisa mejalankan tradisi ini dengan baik para petarung harus melawan dan mengalahkan temannya yang menjadi musuh dalam sebuah pertarungan yang menggunanakan tameng dan rotan. Dan diakhir pertarungan yang mereka lakukan, para petarung harus berjabatan tangan agar proses dari tradisi ini berjalan dengan baik, dan turunlah hujan menguyur desa tersebut. (Topata, n.d.)

\section{Desain Karakter}

Karakter yang ada di dalam game, sebagai berikut:

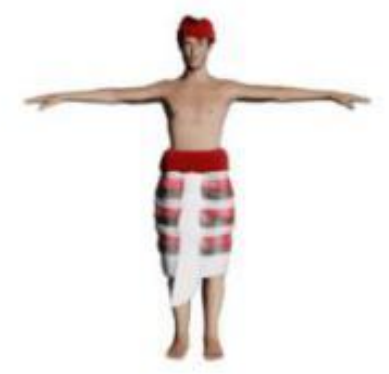

Gambar 1 Karakter Pemain

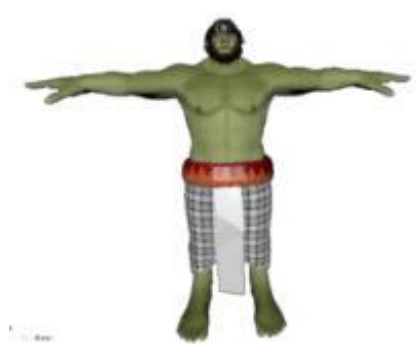

Gambar 2 Karakter Musuh (AI) 


\section{d $\quad$ Alur sistem}

Alur sistem dalam permainan Gebug Ende Seraya Karangasem

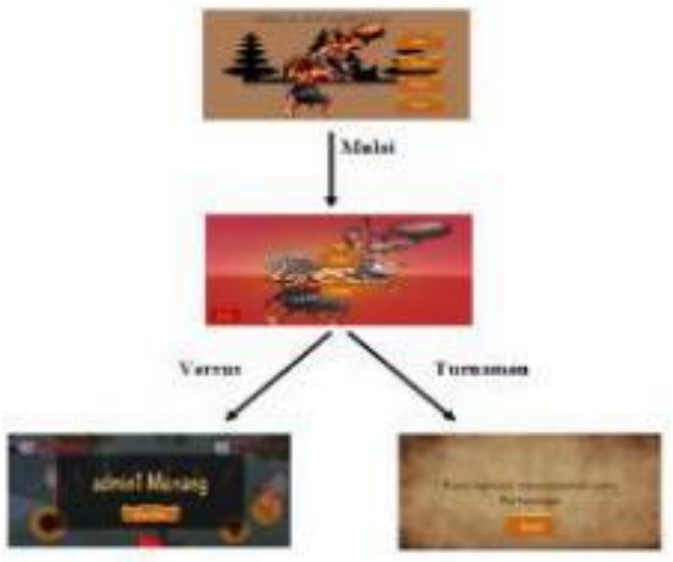

Gambar 3. Alur system Mode Turnamen

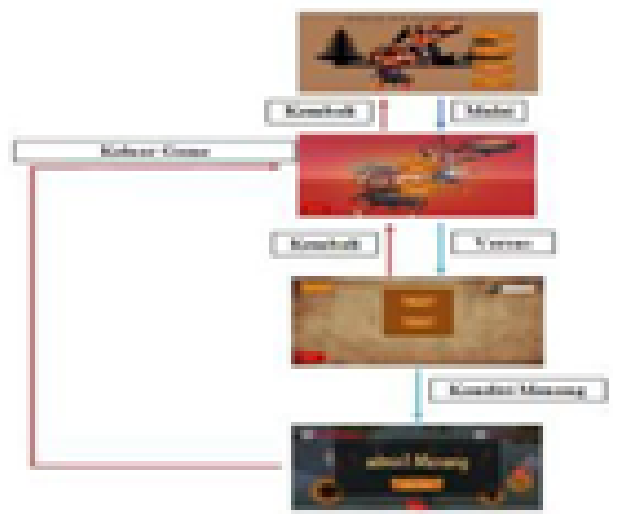

Gambar 4. Alur Sistem Mode Versus

\section{e Antarmuka Permainan}

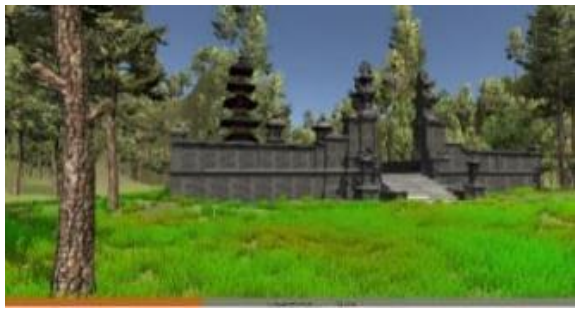

Gambar 5. Loading

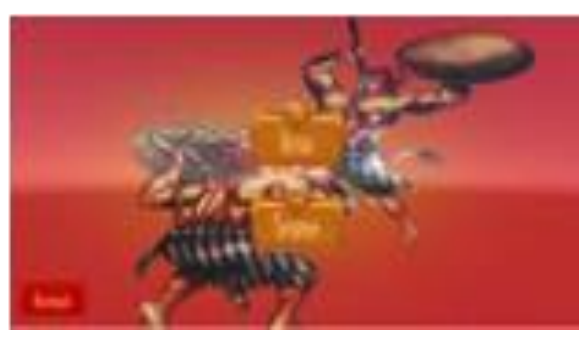

Gambar 7. Mode Permainan

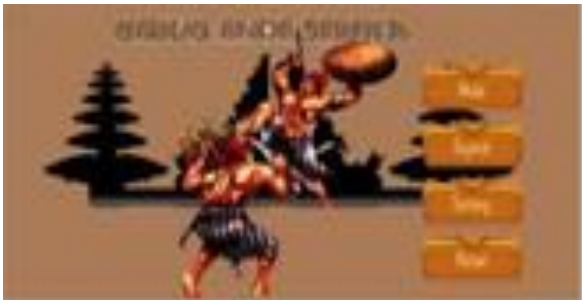

Gambar 6. Menu Utama

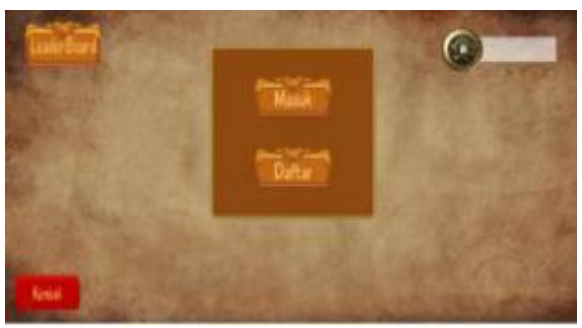

Gambar 8. Mode Versus 


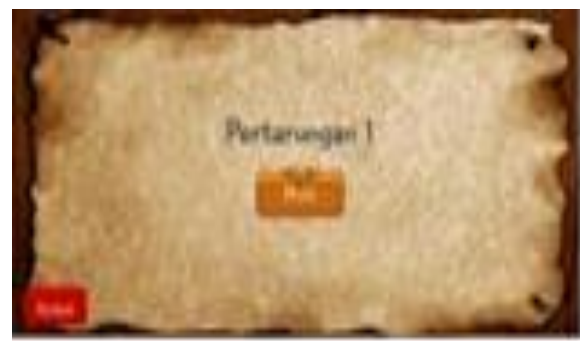

Gambar 9. Pertarungan 1

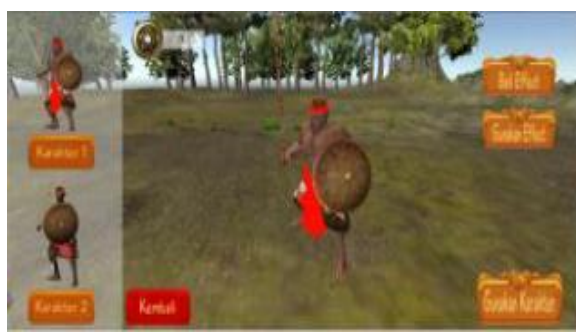

Gambar 11. Pilih Karakter

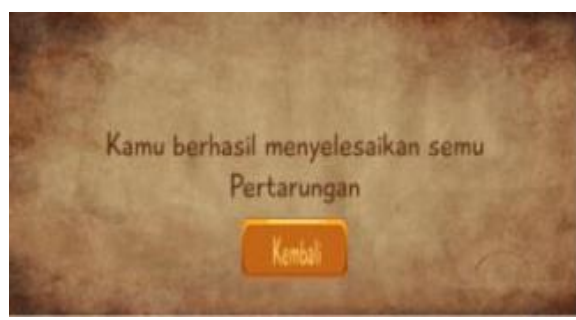

Gambar 13. Kodisi Menang pada mode turnamen

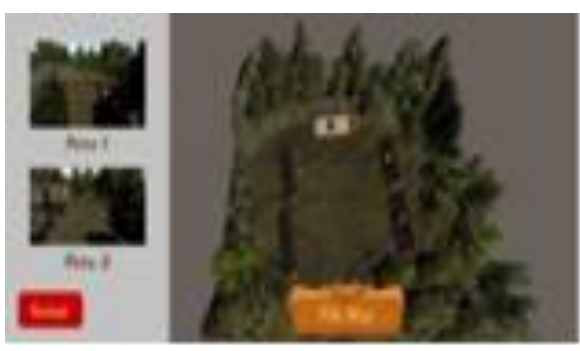

Gambar 10. Pilih Peta

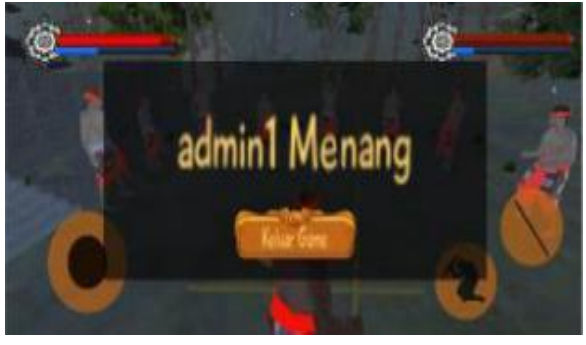

Gambar 12. Kondisi menang pada mode versus

\section{Hasil Tahap Production}

Setelah tahapan Pre-production selesai maka dilanjutkan ketahap Production, dalam tahapam production berisi kegiatan rancangan yang telah dibuat sebelumnya diimplementasikan dengan perangkat lunak yang telah disesuaikan. Pada tahapan ini dilakukan pembuatan asset yang akan dipakai, pembuatan source code, dan pengintegrasian kedua elemen tersebut.

\section{Hasil Tahap Testing}

Testing atau pengujian perangkat lunak merupakan proses menjalankan dan mengevaluasi sebuah perngkat lunak untuk menguji apakah perangkat lunak sudah memenuhi persyaratan atau belum untuk menentukan perbedaan antara hasil yang diharapkan denagn hasil sebenarnya.

\section{a Tujuan Pengujian Perangkat Lunak}

Pengujian perangkat lunak pada Game Multiplayer Pengenalan Budaya Gebug Ende Seraya Karangasem Berbasis Android dilakukan melalui beberapa tahap pengujian yaitu, blackbox Testing, uji ahli media, uji ahli isi, dan UEQ. Tujuan pengujian perangkat lunak pada Game Multiplayer Pengenalan Budaya Gebug Ende Seraya Karangasem Berbasis Android, yaitu:

- Menguji kebenaran alur proses dalam menjalankan Game Multiplayer Pengenalan Budaya Gebug Ende Seraya Karangasem Berbasis Android.

- Menguji pengguna Game Multiplayer Pengenalan Budaya Gebug Ende Seraya Karangasem Berbasis Android pada perangkat smartphone yang berbeda 
- Mengetahui tingkat penilaian dari ahli media terkait tingkat usability dari Game Multiplayer Pengenalan Budaya Gebug Ende Seraya Karangasem Berbasis Android.

- Mengetahui tingkat penilaian dari ahli isi terkait tingkat keakuratan cerita yang dibawakan pada Game Multiplayer Pengenalan Budaya Gebug Ende Seraya Karangasem Berbasis Android.

- Mengetahui respons pengguna setelah menggunakan Game Multiplayer Pengenalan Budaya Gebug Ende Seraya Karangasem Berbasis Android

\section{b Pelaksanaan Pengujian Perangkat Lunak}

Berdasarkan tata ancang dan teknik pengujian perangkat lunak di atas, maka pelaksanaan pengujian perangkat lunak pada Game Multiplayer Pengenalan Budaya Gebug Ende Seraya Karangasem Berbasis Android di antaranya yaitu pelaksanaan pengujian fungsional (blackbox), pengujian ahli isi, pengujian ahli media dan pengujian respon pengguna menggunakan User Experience Questionnaire (UEQ).

- Pelaksanaan Pengujian Fungsional (blackbox)

Pada pelaksanaan pengujian Blackbox dilakukan dengan melakukan pengujian kebenaran proses terhadap aplikasi Game Multiplayer Pengenalan Budaya Gebug Ende Seraya Karangasem Berbasis Android. Pengujian blackbox perangkat lunak ini dilakukan untuk menguji seluruh fungsional dari setiap form yang ada dalam aplikasi Game Multiplayer Pengenalan Budaya Gebug Ende Seraya Karangasem Berbasis Android berjalan dengan baik.

Tabel 1. Uji Coba Compatibility

\begin{tabular}{lcc}
\hline \multicolumn{1}{c}{ Nama } & Merek Smartphone & Versi Sistem Operasi \\
\hline Yoga & Xiaomi Redmi 6 & Android 9.0 Pie \\
Sudarma & Asus Zenfone Max Pro & Android 8.0 Oreo \\
Wahyu & Oppo A83 & Android 7.1 Marhmallow \\
Komang Adi & Asus Zenfone 5 & Android 6.0 Lolipop \\
Winaerta & Samsung E7 & Android 4.4 KitKat \\
\hline
\end{tabular}

\section{c Pelaksanaan Pengujian Ahli Isi}

Pengujian ahli isi dilakukan untuk mengetahui isi dari budaya yang dibawakan apakah sudah sesuai dengan budaya aslinya yang diketahui oleh masyarakat luas. Pelaksanaan uji ahli isi melibatkan dua orang ahli yaitu Bapak Dr. Drs I Made Pageh, M. Hum. sebagai ahli isi 1, yang merupakan dosen di Fakultas Hukum dan Ilmu Sosial Undiksha Singaraja dan Bapak I Putu Ngurah Juniarta S.E, sebagai ahli isi 2 yang merupakan Kelian Adat di Desa Seraya Timur.

Validitas dihitung dengan menggunakan rumus Gregory sebagai berikut:

Keterangan :

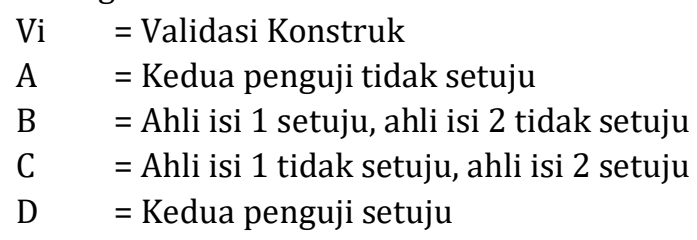

$$
V i=\frac{D}{A+B+C+D}
$$

Koefisien validasi isi didapatkan yaitu 1. Berdasarkan kriteria, validitas isi sangat tinggi. Ini berarti isi game menurut ahli isi 1 dan ahli isi 2 sudah valid.

\section{d Pelaksanaan Pengujian Ahli Media}

Pengujian ahli media berfokus pada penilaian aplikasi Game Multiplayer Pengenalan Budaya Gebug Ende Seraya Karangasem Berbasis Android yang digunakan untuk mendapatkan suatu kesimpulan berupa apakah apliaksi siap untuk uji coba lapangan atau tidak. Pelaksanaan uji ahli media melibatkan dua orang ahli media yaitu Bapak I Made Ardwi Pradnyana, S.T, M.T sebagai ahli media 1 dan Bapak Dr. I Made Gede Sunarya, S.Kom., M.Cs sebagai ahli media 2, beliau berdua merupakan dosen di Fakultas Teknik Dan Kejuruan, Universitas Pendidikan Ganesha. 
Validitas dihitung dengan menggunakan rumus Gregory sebagai berikut:

Keterangan :

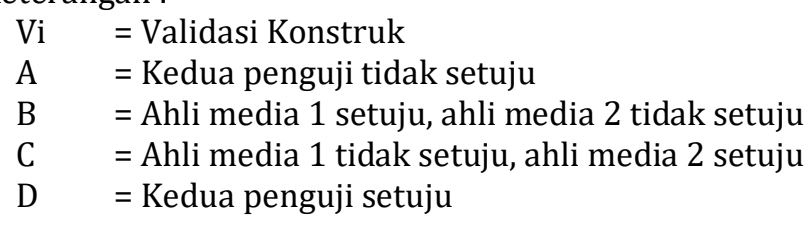

$$
V i=\frac{D}{A+B+C+D}
$$

Koefisien validasi isi didapatkan yaitu 1. Berdasarkan kriteria, validitas media sangat tinggi. Ini berarti isi game menurut ahli media 1 dan ahli media 2 sudah valid.

\section{e Pelaksanaan Pengujian Lapangan}

Pengujian lapangan dilakukan untuk mengetahui respons dari pengguna setelah menggunakan Game Multiplayer Pengenalan Budaya Gebug Ende Seraya Karangasem Berbasis Android, baik itu respons positif maupun negatif. Uji lapangan menggunakan Pengujian UEQ (User Experience Questionnaire) yang merupakan sebuah metode pengukuran UX.

Setelah dilakukan analisis terhadap hasil dari pengujian respons pengguna secara keseluruhan berdasarkan 6 kategori, nilai yang diperoleh dari masing-masing kategori mendapatkan nilai positif yaitu :

1) Daya Tarik memperoleh nilai sebesar 1,767 (positif) secara suka dan tidak suka dapat diartikan bahwa aplikasi memiliki daya tarik yang baik dan disukai oleh pengguna.

2) Kejelasan memperoleh nilai sebesar 1,790 (positif) secara kemudahan dalam menggunakan aplikasi dapat diartikan bahwa aplikasi mudah digunakan oleh pengguna.

3) Efisiensi memperoleh nilai sebesar 1,850 (positif) secara efisien dan cepat dapat diartikan bahwa aplikasi dapat bekerja dengan baik, terorganisir, dan dapat dimengerti oleh pengguna.

4) Ketepatan memperoleh nilai sebesar 1,400 (positif) secara secara penggunaan interaksi, keamanan, dan sesuai harapan dapat diartikan bahwa aplikasi dapat memenuhi keamaan, interaksi, dan sesuai dengan harapan dari pengguna saat menggunakan aplikasi.

5) Stimulaasi memperoleh nilai sebesar 1,890 (positif) secara secara respon pengguna yang menarik dan menyenangkan dapat diartikan bahwa aplikasi dapat memberikan respon yang menyenangkan dan menarik perhatian pengguna.

6) Kebaruan memperoleh nilai sebesar 1,570 (positif)secara kreatif dan inovatif bahwa aplikasi memiliki daya inovati dan kreativitas yang dapat dimengerti oleh pengguna.

Sehingga dapat dikatakan bahwa aplikasi ini mendapatkan respons yang baik atau positif, dan aplikasi memiliki tingkat kejelasan, efisiensi, ketepatan, stimulasi, dan kebaruan yang baik sehingga dapat digunakan oleh masyarakat umum.

\section{E. Pembahasan}

\section{a Alur mekanisme Synchronous Multiplayer}

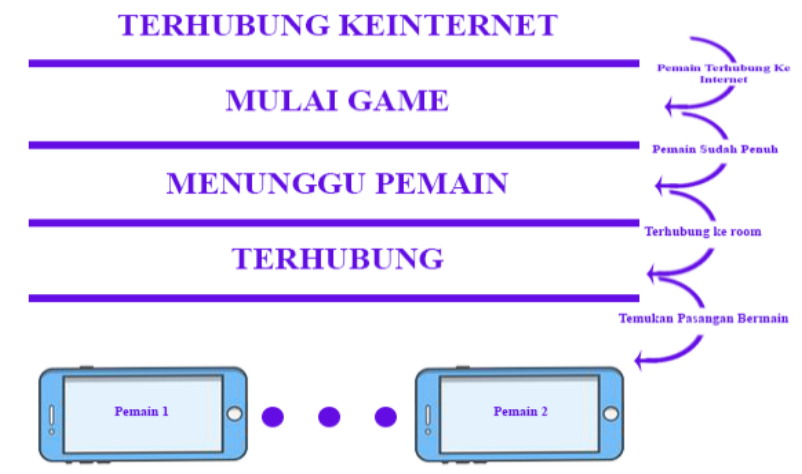

Gambar 14. Alur mekanisme Synchronous Multiplayer 
Keterangan :

1. Pemain Terhubung Ke Internet

Pemain harus terhubung ke internet agar bisa memulai permainan

2. Mulai Game

Ketika pemain sudah dinyatakan penuh, aplikasi permainan dapat memulai permainan dengan ketentuan sebagai berikut :

a) Memulai hitung mundur untuk memulai dan tersinkronisasi dengan klien lainnya

b) mengupdate leaderboard yang tersinkronisasi dengan klien lainnya

c) Melakukan sinkronisasi pada pergerakan tiap pemain, darah dan tenaga pemain

3. Menunggu Pemain

Ketika pemain belum menemukan lawan bermain atau belum ada yang masuk kedalam room maka system akan menampilkan informasi menunggu pemain

4. Terhubung

Pemain memilih tombol Mulai dan aplikasi permainan akan menghubungkan ke Photon Cloud. Setelah terhubung, aplikasi permainan dapat melakukan matchmaking untuk alokasi room untuk mempertemukan antar pemain

Pengembangan Game Multiplayer Pengenalan Budaya Gebug Ende Seraya Karangasem Berbasis Android diimplementasikan dengan menggunakan fitur-fitur yang terdapat pada game engine Unity $3 D$. Pengembangan Game Multiplayer Pengenalan Budaya Gebug Ende Seraya Karangasem Berbasis Android dibuat berdasarkan rancangan-rancangan antarmuka dan gameplay yang sebelumnya telah dirancang. Pengujian Game Multiplayer Pengenalan Budaya Gebug Ende Seraya Karangasem Berbasis Android bertujuan untuk mengetahui tingkat kelemahan serta kesalahan (error) dari aplikasi yang dikembangkan. Sehingga aplikasi masih bisa diperbaiki untuk mengurangi kesalahan-kesalahan yang terjadi sebelum diimplementasikan ke masyarakat luas.

Pengujian yang pertama yaitu pengujian blackbox. Pengujian blackbox dilakukan untuk mengetahui aplikasi yang dibuat sudah berjalan dengan baik dan benar dan dapat digunakan oleh orang lain. Pengujian blackbox dilakukan oleh pengembang sendiri, yang mana hasil dari pengujian kebenaran proses aplikasi yang telah dilakukan menunjukkan bahwa semua proses aplikasi dari pertama dijalankan sampai dengan selesai berfungsi dengan baik.

Pengujian kedua yaitu pengujian ahli isi dilakukan oleh dua orang sebagai ahli isi, yaitu Bapak Dr. Drs I Made Pageh, M. Hum. sebagai ahli isi 1, yang merupakan dosen di Fakultas Hukum dan Ilmu Sosial Undiksha Singaraja dan Bapak I Putu Ngurah Juniarta S.E, sebagai ahli isi 2 yang merupakan Kelian Adat di Desa Seraya Timur mendapatkan kesimpulan bahwa isi cerita dalam game sudah sesuai.

Pengujian ketiga yaitu pengujian ahli media terhadap Game Multiplayer Pengenalan Budaya Gebug Ende Seraya Karangasem Berbasis Android dilakukan oleh dua dosen, yaitu Bapak I Made Ardwi Pradnyana, S.T, M.T sebagai ahli media 1 dan Bapak Dr. I Made Gede Sunarya, S.Kom., M.Cs sebagai ahli media 2, beliau berdua merupakan dosen dilingkungan Fakultas Teknik dan Kejuruan. Game Multiplayer Pengenalan Budaya Gebug Ende Seraya Karangasem Berbasis Android mendapatkan kesimpulan keseluruhan bahwa game sudah sesuai.

Pengujian tahap akhir pada aplikasi ini dilakukan untuk mengetahui respon pengguna setelah menggunakan aplikasi yang dikembangkan dengan melakukan uji respon pengguna. Jumlah responden yang digunakan dalam pengujian respon ini adalah 25 orang yang terdiri dari kalangan siswa, mahasiswa dan masyarakat umum. Evaluasi melalui pengujian respon pengguna ini dilakukan dengan menggunakan User Experience Questionnaire (UEQ). Sehingga dapat dikatakan bahwa aplikasi ini mendapatkan respons yang baik atau positif, dan aplikasi memiliki tingkat kejelasan, efisiensi, ketepatan, stimulasi, dan kebaruan yang baik sehingga dapat digunakan oleh masyarakat umum.

\section{b Kendala}

Game Multiplayer Pengenalan Budaya Gebug Ende Seraya Karangasem Berbasis Android memiliki kendala berupa belum mampu mengimplementasikan lens theory "The Lens of Emotion" yang artinya dalam pembuatan game harus memperhatikan bagaimana perasaan dari pemain yang memainkan game yang sudah di rancang. Misalnya ketika pemain atau lawan terkena serangan makan muncul effect percikan darah. Lens Theory ini belum diimplementasikan dikarenakan keterbatasan pengetahuan peneliti dalam pengimplementasian dari teori tersebut.

Selama proses pembuatan Game Multiplayer Pengenalan Budaya Gebug Ende Seraya Karangasem Berbasis Android, kendala selanjutnya yang dialami peneliti yaitu waktu dan kemampuan yang terbatas dalam merancang gambar, animasi, dan program dalam pengembangan Game di Unity. Selain itu selama 
proses pengembangan Game peneliti sering memdapat kendala berupa program not responding karena perangkat keras/komputer yang digunakan peneliti masih tergolong perangkat berspesifikasi rendah.

\section{c Harapan Penelitian Selanjutnya}

Harapan kedepeannya untuk pengembangan game yang serupa diharapkan pengembang perlu memperhatikan kendala-kendala saat ini sebagai bahan pertimbangan untuk melakukan pengembangan game berikutnya.

\section{SIMPULAN DAN SARAN}

Simpulan dalam penelitian pengembangan Game Multiplayer Pengenalan Budaya Gebug Ende Seraya Karangasem Berbasis Android yang telah dilakukan adalah sebagai berikut:

1. Game Multiplayer Pengenalan Budaya Gebug Ende Seraya Karangasem Berbasis Android yang telah dikembangkan digunakan menjadi media untuk membangkitkan minat masyarakat untuk mengenal dan melestarikan kebudayaan khususnya tradisi gebug ende seraya yang bersifat edukatif dan menghibur.

2. Game Multiplayer Pengenalan Budaya Gebug Ende Seraya Karangasem Berbasis Android dikembangkan menggunakan metode Game development life cycle pada perangkat mobile bersistem operasi Android

3. Pengujian aplikasi dilakukan dengan 4 jenis pengujian dan mendapatkan hasil sebagai berikut. Pertama, pengujian blackbox mendapatkan hasil bahwa semua fungsi dan fitur-fitur yang ada dapat berjalan dengan baik dan sebagaimana mestinya. Pengujian kedua yaitu pengujian ahli isi dilakukan oleh dua orang sebagai ahli isi dan mendapatkan kesimpulan bahwa isi cerita dalam game sudah sesuai. Pengujian ketiga yaitu pengujian ahli media terhadap Game Multiplayer Pengenalan Budaya Gebug Ende Seraya Karangasem Berbasis Android dilakukan oleh dua dosen dan mendapatkan kesimpulan keseluruhan bahwa game sudah sesuai. Pengujian tahap akhir yaitu uji respon pemain mendapatkan hasil yang baik, dimana setiap komponen yang ada dalam pertanyaan menunjukkan impresi yang positif dengan menunjukkan nilai ke arah angka 1 dan seterusnya.

4. Hasil yang telah diperoleh dari pengujian yang telah dilakukan mendapatkan respon yang sangat baik.

Berdasarkan hasil penelitian dan kesimpulan dari pengembangan Pengembangan Game Multiplayer Pengenalan Budaya Gebug Ende Seraya Karangasem Berbasis Android yang dilakukan saran yang bisa peneliti sampaikan untuk penelitian serupa berikutnya, yaitu :

1. Kedepannya untuk pengembangan game pada Android game juga dapat berinteraksi dengan google play untuk menambah pengalaman pengguna dalam bermain game dan juga memperhatikan kendala-kendala yang dialami oleh pengembang saat ini.

2. Pengembangan game selanjutnya dapat membuat game yang lebih inovatif lagi seperti menambahkan lebih banyak pertarungan pada mode turnamen untuk meningkatkan minat pemain dalam memainkan game.

3. Pengembangan game selanjutnya dapat membuat game yang lebih inovatif lagi dan lebih banyak mengimplementasikan Lenses Theory Desain Game yang ada agar tampilan game dan rule permainan lebih relistis untuk menambah minat pemain dalam memainkan game

\section{Ucapan Terima Kasih}

Skripsi ini dapat penulis selesaikan tepat pada waktunya berkat petunjuk dan bimbingan Tuhan Yang Maha Esa serta kerja sama, motivasi, arahan, bantuan, saran, dan kritik yang bersifat konstruktif dari berbagai pihak. Pada kesempatan ini, penulis menyampaikan ucapan terima kasih serta penghargaan sebagai rasa syukur dan hormat penulis kepada I Gede Mahendra Darmawiguna, S.Kom., M.Sc selaku Pembimbing I atas segala motivasi, bimbingan, dan waktu yang telah diluangkan di tengah - tengah kesibukan beliau kepada penulis sehingga skripsi ini dapat terselesaikan tepat pada waktunya. I Made Putrama, S.T., M.Tech selaku Pembimbing II yang telah banyak meluangkan waktu, tenaga, dan pikiran serta penuh kesabaran dalam memberikan bimbingan kepada penulis sehingga skripsi ini dapat diselesaikan. Seluruh staf dosen di lingkungan Jurusan Pendidikan Teknik Informatika Universitas Pendidikan Ganesha yang telah banyak memberikan bantuan dan motivasi kepada penulis dalam penyusunan skripsi ini. Rekan-rekan mahasiswa Jurusan Pendidikan Teknik Informatika yang telah banyak memberikan dorongan, fasilitas dan dukungan moril dalam penyelesaian skripsi ini. Teman-teman PTI angkatan 2015 yang telah bersama-sama berjuang dari awal perkuliahan sampai sekarang ini 
Keluarga, atas segala dorongan, dukungan, dan motivasi baik material maupun moril demi keberhasilan studi penulis. Semoga Tuhan Yang Maha Esa memberikan karunia atas budi baik dari semua pihak yang telah membantu dalam penyelesaian skripsi ini.

\section{Daftar Pustaka}

Club, B. T. (n.d.). Gebug Ende Seraya. Retrieved February 20, 2020, from https://www.balitoursclub.net/gebug-ende-seraya/

Nyoman Trisna Adi Darma, I Ketut Resika Arthana, I. M. P. (2017). PENGEMBANGAN APLIKASI GAME KISAH PANJI SAKTI BERBASIS MOBILE. JANAPATI (Jurnal Nasional Pendidikan TeknikInformatika), Volume 6.

Rajab, B. A. S., \& Kuswantoro, R. B. H. (2018). Perancangan Game Fighting Peresean Sebagai Media Pengenalan Budaya Suku Sasak. XIII(November), 76-83.

Schell, J. (2014). The Art of Game Design_ A Book of Lenses. Second Edition-A K Peters_CRC Press.

Teknosecret. (2019). Game Development Life Cycle (GDLC). https://teknosecret.wordpress.com/2019/03/28/game-development-life-cycle-gdlc/

Topata, J. (n.d.). Pengertian Budaya. https://www.mypurohith.com/pengertian-budaya/

Utomo, P. R., \& Lakoro, R. (2012). Perancangan Concept Art Game Berlatar Budaya Majapahit Sebagai Media Komunikasi Budaya. Jurnal Sains Dan Seni ITS, 1(1), F1-F5. http://www.ejurnal.its.ac.id 